Journal of Education, Teaching and Learning is licensed under

A Creative Commons Attribution-NonCommercial 4.0 International License.

\title{
Competitive Advantage and Marketing Performance (A Descriptive Survey on Oil Palm Plantation Industries in West Kalimantan Province)
}

\author{
Nurmala $^{1)}$, Saniah ${ }^{2)}$, Sy. Novieyana ${ }^{3)}$, Utin Nina Hermina ${ }^{4}$ \\ 1), 2), 3), 4) State Polytechnic of Pontianak, Indonesia \\ E-mail : bu.nurmala@gmail.com
}

\begin{abstract}
This research analyzes the competitive advantage in order to enhance the marketing performance of oil palm plantation companies in West Kalimantan Province, which aims to: (1) find out the implementation of competitive advantage of the oil palm plantation companies in West Kalimantan Province, (2) find out the achievement of marketing performance of the oil palm plantation companies in West Kalimantan Province, and (3) find out the influence of competitive advantage on the marketing performance of the oil palm plantation companies in West Kalimantan Province. This is a descriptive and verification research that uses a descriptive and explanatory survey on the analysis unit of oil palm plantation companies in West Kalimantan Province. The period of research implementation of two (2) years, divided into two stages; First Stage (2013) and Second Stage (2014). The data are collected using questionnaires as well as interviews and observations. The collected data are further processed using path analysis. The results of the First Stage (2013) research find that only few of the oil palm plantation companies in West Kalimantan Province are able to achieve the marketing performance in high category or above their expected target. This is presumed to be related to the weak competitiveness or competitive advantage of the companies as found in the results of descriptive analysis of this research. In order to understand more of such relatedness, it is necessary to conduct further research of the Second Stage (2014) focusing on investigating the influence of competitive advantage on the marketing performance of oil palm plantation companies in West Kalimantan Province.
\end{abstract}

Keywords: Competitive Advantage, Marketing Performance.

\section{Introduction}

A Plantation sub-sector becomes one of the main sectors for the growth of people's economy in West Kalimantan, since it gives the greatest contribution to the West Kalimantan's Gross Regional Domestic Product (PDRB) compared to any other sub-sectors of the agricultural sector, which is 9.27 percent in 2011 and 8.27 percent in 2012. The plantation commodities developed in West Kalimantan consist of oil palm, deep coconut, natural rubber, coffee, cacao/chocolate, pepper, sago, areca catechu, and jatropha curcas. Oil palm and natural rubber are the main commodities continuously developed in West Kalimantan. 
The size of smallholdings currently in use for all plantation commodities is up to 1,029,497 hectares out of allocated 1.3 million hectares, while the size of private-owned and government-owned large plantations is up to 595,121 hectares in use for oil palm and natural rubber. This plantation size is expected to extend in the future since the people of West Kalimantan are highly aware on the advantages of plantation business.

According to the Provincial labor statistical data West Kalimantan, the number of labors working in smallholding sub-sector is more or less than 2.2 million people or 561,225 head of households or around 43.22 percent of the current population of West Kalimantan that is 5,193,272 people. Since the development of plantation sub-sector provide double effects to other economic development sectors, such number of labor tend to be increasing.

The abovementioned fact shows that the plantation sub-sector contributes significantly to the enhancement of income of the local government and the people of West Kalimantan. Local government's enhanced income means local government's enhanced capability in improving local development in meeting public needs. Meanwhile, people's enhanced income means public opportunity to improve their quality of life in the fields of economy, education and health.

To develop the agriculture in West Kalimantan, 5.2 million hectares of land has been prepared since 1991 and 2.5 million hectares is allocated for developing plantation commodity. Until today, there are 313 companies in West Kalimantan Province with productive plants in an area of 388.000 hectares. Particularly for oil palm as the main commodity, based on the 2012 data of Oil Palm Commodity (Plantation Office (Disbun) of West Kalimantan, 2013), the size of land used is 1,060,251 hectares with total production of 1,007,985 Tons/Year involving plantation farmers of 100,763 Heads of Household (Kepala Keluarga/KK). Ketapang Regency has the widest plantation area of 278,525 Ha with total production of 266,350 Ton/Year involving plantation farmers of $16.891 \mathrm{KK}$.

Oil palm as a plant producing Crude Palm Oil (CPO), while Palm Kernel Oil (PKO) is one of the plantation leading plants as the source of non-oil and natural gas based foreign exchange income for Indonesia. The bright prospect of palm oil commodity in the world trade of vegetable oil has encouraged the Indonesian Government to boost the growth of oil palm plantation area. The growth of oil palm plantation sub-sector in Indonesia cannot be separated from the Government's policy to give incentive and primarily facilitate in licensing and investment subsidy assistance for developing smallholdings with a PIR-Bun pattern and new land clearing for private-owned large plantation area.

Indonesian CPO production in 2012 reaches 27 million tons, equal to $53.39 \%$ of worldwide total CPO production. In 2013, Indonesian CPO production is expected to increase to 30 million tons or grows for $11 \%$. Meanwhile, the CPO market this year shows a stagnant condition as the result of declining demand, primarily from India and China as the world greatest $\mathrm{CPO}$ buyers/importers, and is worsen by increasing substitution products (CPO competitors), which is soybean in Brazil, Argentina, and America. The price of CPO in the world market is currently fluctuating with a range of 810 USD (Rp. 8.9 million) to 870 USD (Rp. 9.5 million) per metric ton. The demand of crude palm oil (CPO) from the world market is expected to be increasing in the future, both in domestic and export markets. Current condition shows that the CPO production of West Kalimantan in 2013 increases for $20.47 \%$ to be 256.57 thousand tons in the fourth quarter of 2012 from 212.98 thousand tons in the fourth quarter of 2011 (Kantor Perwakilan Bank Indonesia Kalimantan Barat, 2013).

In support of oil palm plantation industry in West Kalimantan Province, until 2012, 40 units of oil palm processing factory have been built, producing 1.1 million tons of CPO. In 2013, 10 units of new oil palm processing factory have been built, thus there are 50 factories in total in 2013 in West Kalimantan Province. This is made in support of achieving the targeted 
extension of oil palm plantation in West Kalimantan up to 1.5 million hectares with an improving capability of $\mathrm{CPO}$ production. Most of the $\mathrm{CPO}$ factories or 15 factories are in Ketapang Regency. Meanwhile, nationally, the Indonesian total CPO annual production is up to 21.3 million tons derived from 9 million hectares of oil palm plantation.

Notwithstanding the increasing area of plantation land and total oil palm processing factories in West Kalimantan Province, in its journey, however, this industry encounters many problems such as high achievement of marketing performance which is allegedly closely related to non-strong competitive advantage of the companies. In order to obtain information of current competitive advantage of the oil palm plantation companies in West Kalimantan Province and their achievement of marketing performance, it is necessary to conduct a research through a descriptive survey.

\section{Method}

This research is conducted in two stages, the first stage is conducted in 2013, a descriptive research using descriptive survey method, and the second stage is conducted in 2014, a verification research using explanatory survey method. The hypothetic test in the research with an explanatory survey is conducted using path analysis. The analysis unit in this research is companies, that are the managers of oil palm plantation companies in West Kalimantan Province in total of 70 people selected using a simple random sampling technique from the total population of 184 oil palm plantation companies in West Kalimantan Province. The data is collected in this research using combined techniques, which are observation, interview and questionnaire. In analyzing the problems in this research, the data are collected using questionnaires and interviews with managers of the companies. Meanwhile, observation is conducted in order to obtain initial information of the problems encountered by the companies and to obtain additional information as supplement to the responses to questionnaires in support of more comprehensive discussion of the research results.

Before further processing of the research data, the validity and reliability are tested first in assistance of software SPSS 17.0. The results of test show that 8 items of competitive advantage variable are declared valid and 4 items of marketing performance variable are declared valid. Based on the reliability test using software SPSS 17.0, all valid items of this research are declared reliable with the criteria of Alpha Cronbach coefficient for each of the variables are above 0.7 , which are 0.778 and 0.826 .

\section{Result and Discussion}

Based on the research data of domestic sales volume and domestic market share of the companies in oil palm plantation industry in West Kalimantan Province, we find that:

1) Within the period of 2007-2012, only $18.92 \%$ of the oil palm plantation companies in West Kalimantan Province state that they have achieved the domestic sales volume with high category, which is above $100 \%$ of expectation. Meanwhile, the remaining $81.08 \%$ have growth rate of domestic sales volume with medium category, which is less than $100 \%$ of expectation.

2) Within the period of 2007-2012, only $35.14 \%$ of the oil palm plantation companies in West Kalimantan Province state that they have achieved the domestic market share with high category, which is above $100 \%$ of expectation. Meanwhile, the remaining $64.86 \%$ achieve the market share only with medium category, which is less than $100 \%$ of expectation.

As we can see from the growth rate within the period of 2007-2012, we find that:

1) Only $40.54 \%$ of the oil palm plantation companies in West Kalimantan Province state that their growth rate of domestic sales volume is of high category, which is above $100 \%$ of 
expectation. Meanwhile, the remaining $59.46 \%$ have growth rate of domestic sales volume with medium category, which is less than $100 \%$ of expectation.

2) Only $21.62 \%$ of oil palm plantation companies in West Kalimantan Province state that their growth rate of domestic market share is of high category, which is above $100 \%$ of expectation. Meanwhile, the remaining $72.97 \%$ and $5.41 \%$ respectively have growth rate of domestic market share with medium to low categories, which is less than $100 \%$ of expectation.

The fact above shows that during the period of 2007-2012, less than $30 \%$ of oil palm plantation companies in West Kalimantan Province have marketing performance with high category, which is above $100 \%$ of expectation. Meanwhile, the remaining approximately $70 \%$ have marketing performance with medium to low categories, which is less than $100 \%$ of expectation. This illustrates that the oil palm plantation industry in West Kalimantan Province until 2012 still encounters crucial issues related to marketing performance achievement.

When examined further, based on the results of this research, one of the factors alleged to be the cause of low marketing performance of oil palm plantation companies in West Kalimantan Province is the companies' competitive advantage covering: (1) a company's skill compared to the other company, (2) resources in possession of a company compared to that of the other company, (3) a company's control level compared to the other company, (4) the value of product a company offers compared to the other company, (5) the price of product a company offers compared to the other company, (6) a company's effort to offer its product to the customers compared to the other company, (7) loyalty of a company's customers, (8) a company's market share, (9) a company's ability to generate profit, and (10) reserve from a portion of profit for maintaining competitive advantage.

The research results find:

(1) Only $16.22 \%$ of oil palm plantation companies in West Kalimantan Province state they have high skill compared to the other companies. The remaining $83.78 \%$ still have medium skill.

(2) Only $21.62 \%$ of oil palm plantation companies in West Kalimantan Province state that they have corporate resources with high capability compared to the other companies. The remaining $78.38 \%$ have resources with medium capability.

(3) $56.76 \%$ of oil palm plantation companies in West Kalimantan Province state that their control of company is of good category, while the remaining companies' control of their company is of medium category.

(4) $62.16 \%$ of oil palm plantation companies in West Kalimantan Province state that they offer their product with good value to customers, while the remaining companies state that they offer their product with medium value.

(5) $91.89 \%$ of oil palm plantation companies in West Kalimantan Province state that they offer their product with medium price and the remaining $8.11 \%$ state that the product they offer is expensive.

(6) The effort made by the oil palm plantation companies in West Kalimantan Province in offering their product to customer with medium category is stated by $64.86 \%$ while the remaining $35.14 \%$ state that their effort is strong.

(7) $97.30 \%$ of oil palm plantation companies in West Kalimantan Province state that they have loyal customers, while the remaining $2.70 \%$ have disloyal customers.

(8) $48.65 \%$ of oil palm plantation companies in West Kalimantan Province have high market share and $48.65 \%$ of them state that they have medium market share. The remaining $2.70 \%$ have low market share. 
(9) Corporate capability of generating high profit is stated by $27.03 \%$ of the oil palm plantation companies in West Kalimantan Province. 59.46\% of them state that they have medium capability in generating profit. Meanwhile, the remaining $13.51 \%$ have low capability in generating profit.

(10) $13.51 \%$ of oil palm plantation companies in West Kalimantan Province state that they reserve their profit to maintain their competitive advantage at high category. Meanwhile, $54.05 \%$ of them reserve their profit to maintain their competitive advantage at medium category. The remaining $32.43 \%$ of them state that they reserve their profit to maintain their competitive advantage at low category.

Referring to the foregoing research findings, in order to improve the marketing performance of oil palm plantation companies in West Kalimantan Province, it is necessary to improve their competitive advantage by improving: (1) company's skill, (2) company's resources, (3) offering product at lower price, (4) effort to offer their product, (5) market share, mainly in domestic market, (6) company's capability of generating profit, and (7) reserving a portion of profit to maintain their competitive advantage. This seven improvement methods shall be implemented in consideration of other fields of company's competitive advantage aspect, which are: (1) continuously improving company's control level, (2) offering product with even higher value, and (3) keeping customers to be more loyal to buy their product.

\section{Conclusion}

Overall, the findings of this research reveal that in order to improve the marketing performance of oil palm plantation companies in West Kalimantan Province, they need to pay intention to and implement competitive advantage effectively. The effectiveness of competitive advantage implementation is expected to influence their marketing performance, which needs to be proven in the next stage of research (year 2014).

\section{REFERENCES}

Adu, Kwaku Appiah, 1999, The Impact of Economic Reform on Business Performance: a Study of Foreign and Domestic Firms in Ghana, International Business Review, 8, p. 463-486.

Badri, Masood A., Donald Davis and Donna Davis, 2000, Operation Strategy, Enviromental Uncertainty and Performance: a Path Analytic Model of Industries in Developing Countries, Omega, 28, p. 155-173.

Barney, J.B., 1991, Firm Resources and Sustained Competitive Advantage, Journal of Management, 17 (1), p. 99-120.

Best, Roger J., 2004, Market-based Management, Pearson Education, Inc., New Jersey.

Carpano, Claudio, James J. Chrisman, and Kendall Roth, 1994, International Strategy

and Environment: an Assesment of Performance Relationship, Journal of International Business Studies, Thrid Quarter, p. 639-655.

Cravens, David W., 1996, Pemasaran Strategis, Terjemahan, Edisi Keempat, Erlangga, Jakarta. 
Cravens, David W., Nigel F. Piercy, 2006, Strategic Marketing, McGraw-Hill Higher Education, USA.

Day, George S., 1990, Market Driven Strategy, The Free Press, USA.

Day \& Wensley, 1988, Assesing Advantage: a Framework for Diagnosing Competitive Superiority, Journal of Marketing, April, p.30.

Ernst \& Young, 1990, Total Quality, Home-wood, USA.

Grant, Robert M., 1991, Toward a Knowledge-Based Theory of The Firm, Strategic Management Journal, 17 (Winter Special Issue): 09-122.

Green, Dona H., Donald W. Barclay, and Adrian B. Ryans, 1955, Entry Strategy and Long-Term Performance: Conceptualization and Empirical Examination, Journal of Marketing, October, p. 1-14.

Hall, R., 1992, The Strategic Analysis of Intangible Resources, Strategic Management Journal, 13, pp. 135-144.

Hammel, Gary and C.K. Prahalad, 1994, Competiting for the Future, Havard Business Review, 73 (July-August): 122-128.

Harun Al Rasyid, 1994, Teknik Penarikan Sampel dan Penyusunan Skala, Program Pascasarjana Universitas Padjadjaran, Bandung.

Kim, Linsu, and Yoncheol Lim, 1988, Environment, Generic Strategies, and Performance in Rapidly Developing Country: a Taxonomy Approach, Academic of Management Journal, Vol. 31, No. 4, p. 802-827.

Kotler, Philip and Gary Amstrong, 1994, Principle of Marketing, International Edition, $7^{\text {th }}$ Edition, USA.

Li, Ching Chun, 1975, Path Analysis, A Premier Pacific Groove, California.

Li, Haiyang, 2000, How Does New Venture Strategy Matter in the EnvironmentPerformance Relationship?, Journal of High Technology Management Reseach, 12, p. 183-204.

Lukas, Bryan A. and J. Justin Tan, G. Thomas M. Hult, 2001, Strategic Fit in Transitional Economiecs: the Case of China's Electronic Industry, Journal of Management, 27, p. 409-429.

Luo, Yadong, 1999, Environment-Strategy-Performance Relations in Small Business in China: a Case of Township and Village Enterprise in Southern China, Journal of Small Business Management, January, p. 37-52.

McKee, Daryl O., RajanVaradajan, and William M. Pride, 1989, Strategic Adaptability and Firm Performance: a Market-Contingent Perspective, Journal of Mareketing, July, p. 21-35.

Okoroafo, Sam, and Lloyd C. Russow, 1991, Impact of Marketing Strategy on Performance: Empirical Evidence from Liberalized Developing Country. 
Pelham, Alfred M., 1999, Influence of Environment, Strategy, and Market Orientation on Performance in Small Manufacturing Firms, Journal of Business Reseach, 45, p. 33-46.

Porter, Michael E., 1985, Competitive Advantage, Free Press, New York.

Prawirosentono, Suyadi, 1997, Kebijakan Kinerja Karyawan, EdisiPertama, BPFE, Yogyakarta.

Schull, Patrick L., Peter S. Davis and Michael D. Hartline, 1995, Strategic Adaptation to Extended Rivalry, Journal of Business Review, 33, p. 129-142.

Sitepu, Nirwana, 1994, Analisis Jalur (Path Analysis), Unit Statistika Program Pascasarjana Universitas Padjadjaran, Bandung.

Slater, Staenly F \& John C. Narver, 1994, Does Competitive Environment Moderate the Market Orientation-Performance Relationship?, Journal of Marketing, Vol. 58, January, p. 46-55.

Sucherly, 1996, Strategi Pemasaran dalam Industri Kayu Gergajian dan Pengaruhnya terhadap Penjualan, Suatu Penelitian di Pulau Jawa, Disertasi, Universitas Padjadjaran, Bandung. 